Article

\title{
Supplementing Tropical Cattle for Improved Nutrient Utilization and Reduced Enteric Methane Emissions
}

\author{
Asep I. M. Ali ${ }^{1,+}$, Shimels E. Wassie ${ }^{2,+}$, Daniel Korir ${ }^{3}$, Lutz Merbold ${ }^{3}$, John P. Goopy ${ }^{3}$, \\ Klaus Butterbach-Bahl ${ }^{3,4} \mathbb{D}$, Uta Dickhoefer ${ }^{2}$ and Eva Schlecht ${ }^{1, *} * \mathbb{C}$ \\ 1 Animal Husbandry in Tropics and Subtropics, University of Kassel and University of Göttingen, Steinstr. 19, \\ 37213 Witzenhausen, Germany; asepali76@gmail.com \\ 2 Animal Nutrition and Rangeland Management in the Tropics and Subtropics, Institute of Agricultural \\ Sciences in the Tropics, University of Hohenheim, Fruwirthstr. 31, 70599 Stuttgart, Germany; \\ Shimels_Wassie@uni-hohenheim.de (S.E.W.); uta.dickhoefer@uni-hohenheim.de (U.D.) \\ 3 Mazingira Centre, International Livestock Research Institute (ILRI), 00800 Nairobi, Kenya; \\ D.Korir@cgiar.org (D.K.); L.Merbold@cgiar.org (L.M.); J.Goopy@cgiar.org (J.P.G.); \\ klaus.butterbach-bahl@kit.edu (K.B.-B.) \\ 4 Institute of Meteorology and Climate Research, Atmospheric Environmental Research (IMK-IFU), \\ Karlsruhe Institute of Technology (KIT), 82467 Garmisch-Partenkirchen, Germany \\ * Correspondence: schlecht@uni-kassel.de \\ + These authors contributed equally to the manuscript.
}

Received: 29 March 2019; Accepted: 24 April 2019; Published: 30 April 2019

check for updates

Simple Summary: Quality supplementation of roughage-based cattle diets is recommended to improve the animals' production in tropical regions. We tested the effects of two widely suggested high-quality low-cost feed supplements on feed intake, nutrient utilization and enteric methane emissions of growing female cattle. While free access to urea-molasses blocks did not effectively improve the key variables, sweet potato vine silage, a by-product of sweet potato cultivation, improved diet digestibility as well as the animals' retention of nitrogen and lowered their methane emissions per unit of digested feed. Supplementing productive cattle with sweet potato vine silage can thus concomitantly contribute to better animal performance and lower environmental impact.

Abstract: Given their high nitrogen $(\mathrm{N})$ concentration and low costs, sweet potato vine silage (SPVS) and urea-molasses blocks (UMB) are recommended supplements for tropical regions; therefore, they were investigated in this study. Six heifers were allocated to three diets: the roughage diet (R) consisted of wheat straw (0.61) and Rhodes grass hay (0.39; on dry matter (DM) basis); R + SPVS combined R (0.81) and SPVS (0.19); and with R + UMB animals had access to UMB. During two experimental periods, feed intake, feces and urine excretion, digesta passage, and rumen microbial protein synthesis were determined during seven days and methane emissions during three days. There was no treatment effect $(p>0.05)$ on DM and N intake. Apparent DM digestibility of R + SPVS $(510 \mathrm{~g} / \mathrm{kg})$ was higher $(p<0.05)$ than of $\mathrm{R}(474 \mathrm{~g} / \mathrm{kg})$. Digesta passage and duodenal microbial $\mathrm{N}$ flow were similar for all diets $(p>0.05)$, while $\mathrm{N}$ retention was highest with $\mathrm{R}+\operatorname{SPVS}(p>0.05)$. Methane emissions per unit of digested feed $\left(\mathrm{g} \mathrm{CH}_{4} / \mathrm{kg} \mathrm{dDM}\right)$ were lower $(p<0.05)$ for $\mathrm{R}+\mathrm{SPVS}(55.2)$ than for R (64.7). Hence, SPVS supplementation to poor-quality roughage has the potential to increase diet digestibility and $\mathrm{N}$ retention while reducing $\mathrm{CH}_{4}$ emissions.

Keywords: Boran cattle; greenhouse gas emissions; low-quality roughage; microbial protein synthesis; supplementation; sweet potato vine silage; urea-molasses block 


\section{Introduction}

Smallholder mixed crop-livestock systems provide livelihoods for a billion people and produce a third of global beef and milk [1]. These systems are therefore important for local and regional food provision and rural development, especially in tropical countries. However, intensification of cropping activities in mixed systems is often considered more relevant than strengthening of the livestock component [1]. A major concern in this respect is feed supply, because forage production competes with field crops for land, water, labor and other inputs. Consequently, ruminants in mixed systems are often provided with poor-quality forages or crop residues [2], which supply insufficient energy and nutrients [3,4]. This results in low performance [5], live weight (LW) losses [6,7] and a negative nitrogen $(\mathrm{N})$ balance [6,8]. Furthermore, low crude protein $(\mathrm{CP})$ and high fiber concentrations of poor-quality roughages not only entail low feed dry matter (DM) intake and low diet digestibility [9], but also high enteric methane $\left(\mathrm{CH}_{4}\right)$ emissions [10]. In Brahman heifers, for example, the relationship between $\mathrm{CH}_{4}$ emissions per unit of digested organic matter (dOM) differed between tropical forages of good and poor quality (64.6 versus $75.4 \mathrm{~g} \mathrm{CH}_{4} / \mathrm{kg} \mathrm{dOM}$; [11]). Piñeiro-Vázquez et al. [12] were able to lower $\mathrm{CH}_{4}$ emissions when increasing $\mathrm{N}$ intake of heifers by supplementing their poor-quality Pennisetum purpureum diet with N-rich Leucaena leucocephala. Furthermore, improved fiber digestibility and higher $\mathrm{N}$ retention were observed as intake of L. leucocephala increased [12], most likely due to enhanced microbial $\mathrm{N}$ flow from the rumen to the duodenum stimulated by the legume supplementation [13].

Where land and/or water for cultivating leguminous fodder plants is scarce, leafy crop residues, such as sweet potato vines, with high $\mathrm{CP}$ and low fiber concentration [14-16] may serve as valuable alternative. In many parts of Africa, sweet potato is a regular staple food, even promoted for human diet improvement [17]. Feeding cattle with sweet potato vines is practiced by small-scale farmers in Kenya [3,4] and Nigeria [18]. In dairy cows, this has been shown to improve rumen fermentation, feed digestibility, and milk yield [19], and reduce production costs [18]. Another widely recommended supplement is the urea-molasses block (UMB), due to its easy fabrication and low costs [20]. Increased LW gain with UMB supplementation was reported for grazing dairy heifers in Kenya [21], and improved $\mathrm{N}$ retention was determined in Indian cattle consuming wheat straw supplemented with UMB [8,22]. If optimal amounts of readily degradable protein and energy are supplied by the supplement, rumen microbes can more efficiently break down poorly digestible roughages, which reduces enteric $\mathrm{CH}_{4}$ production, yields higher microbial biomass, enhances post-ruminal availability of amino acids and increases $\mathrm{N}$ retention [22-24]. However, most of the cited studies only investigated one or two of the mentioned processes and implications, rather than analyzing the continuum of supplemented feed intake, digesta passage, diet digestibility, rumen microbial protein synthesis, duodenal microbial $\mathrm{N}$ flow, $\mathrm{N}$ retention and enteric $\mathrm{CH}_{4}$ emission. Such a holistic assessment is however needed to identify feeding strategies that serve a sustainable intensification of tropical crop-ruminant systems. We therefore investigated how supplementing a poor-quality roughage diet of dairy heifers with low-cost high-quality supplements, namely sweet potato vine silage (SPVS) and UMB, affects their digestive processes, enteric $\mathrm{CH}_{4}$ production and rumen microbial protein synthesis.

\section{Materials and Methods}

\subsection{Experimental Design and Animals}

An experiment comprising two periods of five weeks each was conducted at the International Livestock Research Institute (ILRI), Nairobi, Kenya, from September to November 2015. The average daily minimum and maximum ambient air temperature during this period was $14.1^{\circ} \mathrm{C}$ and $26.0^{\circ} \mathrm{C}$, and relative air humidity ranged from an average minimum of $17.0 \%$ to an average maximum of 93.2\% (recorded on site with a H08-032-08 HOBOßTemp/RH logger at $0.5 \mathrm{~h}$ intervals). Each of the two periods was subdivided into: (i) three weeks of adaptation to the diet; and (ii) two sampling weeks including one week of digestibility measurement where feed intake along with feces and urine excretion were measured and one week of respiration chamber measurements of enteric $\mathrm{CH}_{4}$ emissions. 
Six Holstein $\times$ Boran heifers of $148.0 \mathrm{~kg}$ (SD 4.57) initial LW aged 1.3 years were stratified by LW and allocated to three treatments. Crossbreeding local Boran cattle with Holstein Friesian is a common practice in Kenya and neighboring Ethiopia to enhance the milk yield of female individuals. Before starting the experiment, heifers were ear-tagged and subcutaneously vaccinated against foot and mouth disease (inactivated FMD virus strains, $3 \mathrm{~mL} /$ animal; Kenya Veterinary Vaccines Production Institute, Nairobi, Kenya) and clostridia (inactivated bacterin-toxoid, $5 \mathrm{~mL} /$ animal; Jordan Bio-Industries Center, Amman, Jordan). In addition, they were orally treated against endoparasites (Albendazole $10 \mathrm{~g} / \mathrm{L}$; $15 \mathrm{~mL} /$ animal orally; NORBROOK Kenya Ltd., Nairobi, Kenya). The heifers were kept in an open barn with individual pens $(2.0 \mathrm{~m} \times 3.0 \mathrm{~m})$ during adaptation, in individual stands $(1.1 \mathrm{~m} \times 2.2 \mathrm{~m})$ inside a closed barn during digestibility measurements, and in an open circuit chamber (see below) during $\mathrm{CH}_{4}$ measurements. Their LW was determined once weekly before morning feeding (Gallagher weigh scale W210; FarmShop, Queensland, Australia; capacity 2000 kg, accuracy 1\%). The experiment was approved by the Animal Care and Use Committee of ILRI (No. IACUC-RC2015-07) and the animals were under constant observation of a veterinarian.

\subsection{Feeding}

The experimental diets consisted of roughage $(\mathrm{R})$ only (61.4 $\mathrm{g}$ wheat straw and $38.6 \mathrm{~g}$ Rhodes grass hay per $100 \mathrm{~g}$ diet, on DM basis), roughage and sweet potato vine silage ( + SPVS), and roughage plus urea-molasses block ( $+\mathrm{UMB})$. The composition of the roughage, UMB, and SPVS is shown in Table 1. Straw and hay were chaffed to particles of 5-20 cm length and mixed daily, while the silage was prepared three months before the experiment according to the International Potato Centre's brochure [25] by mixing $10 \mathrm{~kg}$ of molasses, $375 \mathrm{~kg}$ of fresh sweet potato vines (leaf and stem), and $175 \mathrm{~kg}$ of fresh roots and fermenting the mixture in 1000-liter silo bags. The urea-molasses block contained $(\mathrm{g} / 100 \mathrm{~g}$ of fresh matter $(\mathrm{FM}))$ : water (5.0), magnesium sulfate (5.0), vegetable oil (1.0), sugarcane molasses (35.0), urea (10.0), sodium chloride (10.0), dicalcium phosphate (18.9), a trace mineral premix (Mn, $\mathrm{Zn}, \mathrm{Cu}$, and Se; 0.1), cement (10.0), and cottonseed meal (5.0).

Table 1. Proximate composition of roughage ${ }^{1}$, sweet potato vine silage (SPVS), and urea-molasses blocks (UMB) offered during the experiment.

\begin{tabular}{ccccccc}
\hline Feed & Period $^{2}$ & $\begin{array}{c}\text { DM } \\
\text { (g/kg FM) }\end{array}$ & OM & $\begin{array}{c}\text { CP } \\
\text { (g/kg DM) }\end{array}$ & NDF \\
\hline Roughage $^{1}$ & 1 & 813 & 889 & 70.3 & 731 & 479 \\
& 2 & 742 & 895 & 72.2 & 738 & 460 \\
SPVS & 1 & 193 & 875 & 136.1 & 537 & 393 \\
& 2 & 199 & 877 & 143.7 & 537 & 393 \\
UMB & 1,2 & 899 & 502 & 373.6 & 27 & 17 \\
\hline
\end{tabular}

$\mathrm{DM}$, dry matter; OM, organic matter; $\mathrm{CP}$, crude protein; NDF, neutral detergent fiber; ADF, acid detergent fiber; FM, fresh matter ${ }^{1}$ Roughage: 0.61 wheat straw +0.39 Rhodes grass hay. ${ }^{2}$ Period 1: 7 September-11 October 2015; Period 2: 12 October-15 November 2015.

The amount of roughage offered to each animal corresponded to $2.5 \mathrm{~g} \mathrm{DM} / 100 \mathrm{~g} \mathrm{LW}$ according to the weekly measured LW; it was adjusted to allow for refusals of 5-10 g/100 g (i.e., ad libitum feeding). For diet R + SPVS, roughage contributed $81 \mathrm{~g}$ and SPVS $19 \mathrm{~g}$ per $100 \mathrm{~g}$ (on DM basis) of the offer. During daily feeding, SPVS was offered once in the morning along with a first offer of roughage. To minimize roughage spillage, the daily portion was stored in a large bag and small amounts were offered at a time. When the trough was emptied to two thirds, new roughage was added until the bag was empty. Daily feeding started at 9:30, after refusals from the previous day had been removed from the trough and weighed (Citizen CTG6H scale, Citizen Scales Inc., New York, USA; capacity $6000 \mathrm{~g}$, accuracy $0.1 \mathrm{~g}$ ). Drinking water and UMB were provided ad libitum and always accessible. 


\subsection{Quantification of Feed Intake, Feces, and Urine Excretion}

In each experimental period, approximately $100 \mathrm{~g}$ FM of offered roughage was sampled after chaffing and mixing ( 2 times per week). Likewise, a representative sample of $300 \mathrm{~g}$ FM of SPVS was collected from each newly opened silage bag, and UMB $( \pm 100 \mathrm{~g} \mathrm{FM})$ was sampled at the moment of UMB preparation. Roughage samples were stored in paper bags at room temperature, while samples of SPVS and UMB were stored in zipper bags in a freezer $\left(-20^{\circ} \mathrm{C}\right)$. During the 7 -day digestibility measurements, individual refusals of roughage and SPVS were collected and weighed daily. Roughage refusals were stored in a large plastic bag, pooled for the week, and then homogenized and subsampled $( \pm 100 \mathrm{~g} \mathrm{FM})$ at the end of the week. SPVS refusals were also stored as a pooled sample at $-20{ }^{\circ} \mathrm{C}$; they were thawed, homogenized, and subsampled $( \pm 100 \mathrm{~g} \mathrm{DM})$ at the end of the week. Consumption of UMB was measured by weighing the blocks before each morning feeding, and daily intake was calculated as the weight difference between two subsequent mornings.

Whenever an animal defecated, the total amount of feces was collected from the clean pen floor. Per animal, feces were collected into a 10-liter bucket and weighed (Citizen CTG6H scale, see above) at 8:00 each day throughout the sampling week. After $24 \mathrm{~h}$, feces were thoroughly mixed and a subsample of $300 \mathrm{~g}$ FM was dried at $50{ }^{\circ} \mathrm{C}$ for $72 \mathrm{~h}$ (Genlab SDO/425/DIG oven, Genlab Ltd., Widnes, $\mathrm{UK})$ and reweighed. Another feces subsample of $60 \mathrm{~g}$ FM was stored frozen $\left(-20^{\circ} \mathrm{C}\right)$ for $\mathrm{N}$ analysis. Dried samples of feed offered, feed refused and of feces were stored in airtight zipper bags at room temperature. At the end of each experimental period, dried samples were ground to pass a 1-mm mesh (IKA®Werke grinder MF 10 basic, Staufen, Germany). Proportional to the daily amount of feces excreted, dried fecal subsamples were pooled per period and homogenized; a final sample of $100 \mathrm{~g}$ DM was kept for analysis. Frozen fecal samples were thawed, pooled in proportion to the daily amount of feces excreted, thoroughly mixed and directly analyzed for $\mathrm{N}$ (see below).

During five consecutive days of the sampling week, total urine excreted by each heifer was quantitatively collected into a closed 5-L container using a urine harness fitted to the animal's vulva [26]. Each bucket contained $100 \mathrm{~mL}$ of $20 \% \mathrm{v} / \mathrm{v}$ sulfuric acid to acidify the urine $(\mathrm{pH}<3)$ and prevent ammonia losses as well as microbial degradation of purine derivatives. After quantifying the excreted daily volume, urine was homogenized, filtered through two layers of surgical gaze and then sampled, whereby $100 \mathrm{~mL}$ were stored at $-20^{\circ} \mathrm{C}$ for $\mathrm{N}$ analysis. For analysis of purine derivatives, $50 \mathrm{~mL}$ of acidified urine sample were filtered through a filter paper (DF 400 185, ALBET LabScience, Dassel, Germany). Thereafter, $20 \mathrm{~mL}$ of the filtrate were diluted with distilled water at a ratio 1:5 and thoroughly mixed. Three aliquots of $15 \mathrm{~mL}$ each were stored at $-20{ }^{\circ} \mathrm{C}$ for analysis.

\subsection{Determination of Digesta Passage}

Liquid and solid digesta passage through the gastrointestinal tract were determined using ytterbium $(\mathrm{Yb})$ marked fiber particles (solid digesta marker) and Cobalt-EDTA (Co-EDTA, liquid digesta marker). To prepare marked fiber, wheat straw was hand-cut to $>3 \mathrm{~cm}$ particle size and then sieved through a $2-\mathrm{cm}$ mesh. Straw remaining on the sieve was boiled for $1 \mathrm{~h}$ in neutral detergent solution free of ethylenediaminetetra-acetic acid (EDTA) and then rinsed repeatedly with tap water. Washed fiber particles were dried for $48 \mathrm{~h}$ at $70{ }^{\circ} \mathrm{C}$ and thereafter soaked for $24 \mathrm{~h}$ in a $12.4 \mathrm{mmol} / \mathrm{L}$ aqueous solution of ytterbium (III) acetate tetrahydrate. Afterwards, marked fiber was again rinsed with tap water and then soaked for $6 \mathrm{~h}$ in an acetic acid solution $(100 \mathrm{mmol} / \mathrm{L})$ to discard unabsorbed $\mathrm{Yb}$ [27]. After another rinse with tap water, the fiber was dried at $70{ }^{\circ} \mathrm{C}$ for $48 \mathrm{~h}$ and stored. The final concentration of $\mathrm{Yb}(8.46 \mathrm{mg} / \mathrm{g} \mathrm{DM})$ was determined from a $0.5 \mathrm{~g}$ sample of marked fiber (see below).

Co-EDTA marker was prepared according to Uden et al. [28]: $249.08 \mathrm{~g}$ cobalt(II) acetate tetrahydrate, $43 \mathrm{~g}$ lithium hydroxide, and $292.24 \mathrm{~g}$ EDTA were dissolved in a 10-L beaker containing $2 \mathrm{~L}$ of Milli-Q distilled water. Hydrogen peroxide $(200 \mathrm{~mL}, 30 \% \mathrm{v} / \mathrm{v})$ was added to the solution; after overnight equilibration, $3 \mathrm{~L}$ of ethanol $(95 \% \mathrm{v} / \mathrm{v})$ were added and the mixture was refrigerated at $4{ }^{\circ} \mathrm{C}$. The resulting precipitate was filtered (Whatman No. 2 filter paper) and washed thoroughly with $80 \% \mathrm{v} / \mathrm{v}$ ethanol. The precipitate was dried overnight at $65^{\circ} \mathrm{C}$ and stored in an airtight bag. 
Before morning feeding on Day 1 of the sampling week, each heifer was fed a single pulse dose of marked fiber corresponding to $5.6 \mathrm{mg} \mathrm{Yb}$ per kg LW [29]. The fiber particles were mixed with $20 \mathrm{~g}$ of molasses. As soon as a heifer had completely consumed the marked fiber, it was drenched with Co-EDTA at $23.56 \mathrm{mg} / \mathrm{kg} \mathrm{LW}$. The time of marker application $\left(\mathrm{t}_{0}\right)$ was individually recorded as the moment a heifer had been drenched with Co-EDTA. Fecal samples for $\mathrm{Yb}$ and $\mathrm{Co}$ analysis were collected by gentle anal stimulation and grab-sampling of fresh feces at $0,4,6,8,10,12,14,16,20,24$, $28,32,36,40,46,52,58,64,70,76,82,88,96,104,112,120,128,136$, and $148 \mathrm{~h}$ after dosing the markers. Fresh samples were weighed, homogenized, and about $60 \mathrm{~g}$ FM were kept for marker determination, while residual material was collected into the 10-liter bucket for daily fecal sampling (see above). Marker-containing samples were dried at $50{ }^{\circ} \mathrm{C}$ for $72 \mathrm{~h}$, reweighed, ground to pass a 1-mm mesh (see above), and stored in air-tight zipper bags until analysis.

\subsection{Quantification of Enteric Methane Emissions}

Methane measurements were carried out in three respiration chambers $(3.0 \mathrm{~m} \times 1.5 \mathrm{~m}, 3 \mathrm{~m}$ height; No Pollution Industrial Systems Ltd, Edinburgh, UK) during $22 \mathrm{~h}$ on each of 3 days per animal and period, with subsequent measurements separated by one day. At 10:00 on a measurement day, the animal was positioned in the chamber where it was awaited by its feed; drinking water was automatically supplied. At 8:00 on the following day, the animal returned to the open barn and the chamber was cleaned, feed refusals were quantified and feed was placed for the new animal, which again entered at 10:00.

During each $22 \mathrm{~h}$ measurement, the concentration of $\mathrm{CH}_{4}[\mathrm{ppm}]$ in the inlet and outlet air stream was measured every $10 \mathrm{~min}$ for $90 \mathrm{~s}$ by a Picarro G2508 Cavity Ringdown spectrometer (Piccaro Inc. California, USA). The analyzer was equipped with pumps connected to the incoming and exhaust air streams of the chamber and to two computers that controlled air condition, flow rate, and recorded gas concentrations on a continuous basis. Total $\mathrm{CH}_{4}$ emission $(\mathrm{g} / 22 \mathrm{~h})$ was calculated as chamber airflow multiplied by the $\mathrm{CH}_{4}$ concentration in the chamber, adjusted for the $\mathrm{CH}_{4}$ concentration of the incoming air, temperature, recovery rate, and atmospheric pressure in the chamber, and then converted to daily $\mathrm{CH}_{4}$ emission.

\subsection{Chemical Analysis of Samples}

Samples of feed offered and refused and of feces were analyzed for their concentrations of DM (method 967.03; AOAC [30]) and crude ash (method 924.05; AOAC [30]). Concentration of organic matter $(\mathrm{OM})$ was obtained by subtracting the concentration of crude ash $(\mathrm{g} / 100 \mathrm{~g} \mathrm{DM})$ from 100 . According to VDLUFA [31], neutral detergent fiber (NDF; method 6.5.1, using alpha-amylase) and acid detergent fiber (ADF; method 6.5.2) concentrations-including residual ash-were determined using a FibertecTM FOSS analyser (Foss GmbH; Hamburg, Germany). The N concentration in feedstuffs offered and refused, as well as in thawed feces and urine, was determined by the Kjeldahl procedure (method 988.05; AOAC [30]) using a Tecator 1028 distilling unit (Tecator GmbH; Hagen, Germany); $\mathrm{CP}$ concentration was obtained by multiplying $\mathrm{N}$ concentration with factor 6.25 . All analyses were done in duplicate and repeated if differences between replicates were $>5 \%$ of the mean.

Marker-containing fecal samples underwent sealed chamber digestion to determine $\mathrm{Yb}$ and $\mathrm{Co}$ concentrations [32]. Each sample was weighed $(0.5 \pm 0.01 \mathrm{~g}$ DM; Mettler Toledo XP205; Giessen, Germany) and placed in a pre-weighed $100 \mathrm{~mL}$ Schott bottle. Two milliliters of a freshly prepared perchloric acid/hydrogen peroxide mixture $(7: 3 \mathrm{v} / \mathrm{v})$ were placed in the bottle, and contents were allowed to oxidize overnight in a fume cupboard. Then, $1 \mathrm{~mL}$ of hydrogen peroxide was added, the bottle was tightly sealed and placed in the oven at $80^{\circ} \mathrm{C}$ for 30 minutes. After the bottle had cooled down, another $1 \mathrm{~mL}$ of hydrogen peroxide was added, and the tightly sealed bottle was placed in the oven $\left(80^{\circ} \mathrm{C}\right)$ for 60 minutes. Afterwards, the sample was equilibrated to $20 \mathrm{~g}$ by addition of distilled water, shaken, filtered to remove silica precipitates (Whatman No. 1 filter paper), and stored at $2{ }^{\circ} \mathrm{C}$ until analysis. To check precision of digestion procedure and subsequent spectroscopy, every 10th 
sample was digested in duplicate. $\mathrm{Yb}$ and Co concentrations of the solution $(\mathrm{mg} / \mathrm{L})$ were determined by inductively coupled plasma optical emission spectroscopy (ICP-OES 5100 VDV, Agilent Technologies; Santa Clara, USA) after 1:10 dilution with distilled water. $\mathrm{Yb}$ and Co concentrations in feces (mg/g DM) were calculated based on dilution, equilibrated weight, and dry sample weight.

To determine microbial $\mathrm{N}$ supply to the host animal, the daily excretion of purine derivatives (PD; allantoin, uric acid, xanthine, and hypoxanthine) was determined by colorimetry [33]. Creatinine was also analyzed colorimetrically using the Jaffe alkaline picrate reaction. The diluted urine samples were thawed, homogenized, and further diluted with distilled water at $1: 30 \mathrm{v} / \mathrm{v}$ to achieve a total PD concentration in the sample of 10-50 mg/L. Absorbance of allantoin was determined at $522 \mathrm{~nm}$ and of uric acid at $293 \mathrm{~nm}$ (Shimadzu@UV-150-02 spectrophotometer; Shimadzu Corporation, Kyoto, Japan). Xanthine and hypoxanthine concentrations were derived from uric acid concentration after treating the samples with xanthine oxidases (X1875-5UN; Sigma-Aldrich Chemie GmbH Steinheim, Germany). Allantoin, uric acid, and xanthine plus hypoxanthine excretions (mmol/day) were obtained by multiplying their molar concentrations $(\mathrm{mmol} / \mathrm{L})$ with daily urine excretion; adding up the individual values resulted in total PD excretion (mmol/day).

\subsection{Data Analysis}

Statistical analyses were performed using SAS 9.1 (SAS Institute Inc. Cary, NC, USA); results are presented as arithmetic treatment means and standard error of the mean unless specified otherwise. Feed and nutrient intake was calculated by subtracting an animal's daily amount of feed refusals (and the nutrients contained therein) from the daily amount of feed (nutrients) offered. The concentration of nutrients in the ingesta, namely the actually consumed feed, was calculated by dividing the amount of a specific nutrient by total feed DM intake. Apparent total tract digestibility ("digestibility") of feed $\mathrm{DM}, \mathrm{OM}, \mathrm{NDF}$, and $\mathrm{ADF}$ was calculated by subtracting the amount excreted via feces from the respective amount ingested and dividing the difference by the ingested amount.

The cumulative amount of $\mathrm{Yb}$ and Co excreted in the sampling week was calculated from the concentration of the respective element in individual fecal samples multiplied by the respective fecal mass at time $t_{i}$ (sampling time). Based on the one-compartment Gamma-2 model of Richter and Schlecht [29], the NLIN procedure (PROC NLIN method = dud) was applied to compute first-time appearance of marker in feces (TT; equivalent to post-ruminal laminar flow), ruminal passage rate $(\lambda)$, retention time in the mixing compartment (CMRT: $\left.2 \lambda^{-1}\right)$, and retention time in the total gastrointestinal tract (TMRT: CMRT+TT) for parameters of solid ( $s$ ) and liquid ( $l$ ) digesta passage.

An animal's nitrogen retention was calculated by subtracting $\mathrm{N}$ excretion in feces and urine from $\mathrm{N}$ intake. The amount of microbial PD $(X)$ absorbed at the duodenum was calculated from PD excretion (Y) as proposed by Wassie et al. [34]:

$$
\mathrm{Y}=0.85 \mathrm{X}+\left(0.243 \mathrm{LW}^{0.75}\right)
$$

where $\mathrm{Y}$ is PD excretion (mmol/day), $\mathrm{X}$ is the amount of microbial PD absorbed at the duodenum $(\mathrm{mmol} /$ day), and LW $(\mathrm{kg})$ is the animal's live weight. Factor 0.243 represents the average daily excretion of endogenous PD in zebu cattle [34].

Duodenal microbial N flow (g/d; also referred to as "microbial N") was estimated from absorbed $\mathrm{PD}(\mathrm{X}$ in Equation (1)) as follows:

$$
\text { Microbial } \mathrm{N}=\mathrm{X} * 70 /(0.116 * 0.83 * 1000)
$$

where $\mathrm{X}$ is the duodenal absorption of microbial PD (mmol/day), 70 is the $\mathrm{N}$ concentration of purines ( $\mathrm{mg} \mathrm{N} / \mathrm{mmol}), 0.83$ is the intestinal digestibility of microbial purines, and 0.116 is the ratio of purine $\mathrm{N}$ to total $\mathrm{N}$ in mixed rumen microbes. The efficiency of microbial protein synthesis (EMPS) was expressed in three different way, namely as g microbial $\mathrm{N}$ (for calculation see Equation (2)) per unit of ingested OM (g N/kg OM), ingested $\mathrm{N}(\mathrm{g} \mathrm{N} / \mathrm{g} \mathrm{N})$, and digested $\mathrm{OM}(\mathrm{g} \mathrm{N} / \mathrm{kg} \mathrm{dOM})$. 
Data from 2 periods $\times 3$ treatments $\times 2$ animals were obtained for feed intake, digestibility, digesta passage parameters, $\mathrm{N}$ retention, microbial $\mathrm{N}$ flow, and $\mathrm{CH}_{4}$ emissions. Analysis of variance (PROC MIXED) was performed with diet and period as fixed effects and animal as random factor:

$$
\mathrm{y}_{\mathrm{ijk}}=\mu+d_{\mathrm{i}}+p_{\mathrm{j}}+d p_{\mathrm{ij}}+a_{\mathrm{k}}+e_{\mathrm{ijk} \mathrm{l}}
$$

where $\mathrm{y}_{\mathrm{ijk}}$ is the dependent variable for a particular ijk case, $\mu$ is the overall mean, $d_{\mathrm{i}}$ is the effect of diet $\mathrm{i}, p_{\mathrm{j}}$ is the effect of period $\mathrm{j}, a_{\mathrm{k}}$ is the random effect of animal $\mathrm{k}$, and $e_{\mathrm{ijk}}$ is the residual error.

The Tukey post-hoc test was applied to detect significant differences between diet and period means, respectively. Significance was declared at $p \leq 0.05$, and a trend was considered to exist if $0.05<$ $p \leq 0.10$. The relationship between feed intake, ingesta quality and rate of passage parameters was tested by Spearman rank correlation (PROC CORR). Linear regression (PROC REG) was used to test the relationship between DM intake (DMI) and daily $\mathrm{CH}_{4}$ emission.

\section{Results}

\subsection{Feed Intake, Ingesta Composition, Digestibility, and Digesta Passage}

The offered roughage was characterized by high NDF and ADF concentrations and a low CP content, whereas SPVS and UMB were low in NDF and ADF and high in CP (Table 1). Even though for all nutrients highest intake values $\left(\mathrm{g} / \mathrm{kg}^{0.75} \mathrm{LW}\right)$ were determined for $\mathrm{R}+\mathrm{SPVS}$, there was no effect of diet on the quantitative intake of $\mathrm{DM}, \mathrm{OM}, \mathrm{NDF}, \mathrm{ADF}$, and $\mathrm{CP}$ (Table 2). Ingesta CP concentration was higher for $\mathrm{R}+\mathrm{SPVS}$ than for $\mathrm{R}+\mathrm{UMB}$ and $\mathrm{R}$. Dry matter digestibility was higher for $\mathrm{R}+\mathrm{SPVS}$ than for $\mathrm{R}$ but not different from $\mathrm{R}+\mathrm{UMB}$, while OM digestibility of $\mathrm{R}+\mathrm{SPVS}$ tended to be higher than of $\mathrm{R}$ and $\mathrm{R}+\mathrm{UMB}$. No difference between diets existed for NDF and ADF digestibility (Table 2). Among all observed variables, only NDF intake was influenced by experimental period $(p=0.04)$ with the value in Period 2 being higher than in Period 1. A significant diet $\times$ period interaction was also obtained for NDF digestibility $(p=0.049)$.

Table 2. Quantitative intake, ingesta composition, and digestibility of proximate nutrient and fiber fractions in heifers fed roughage $(\mathrm{R})^{1}$ alone or supplemented with sweet potato vine silage (R + SPVS) or urea-molasses blocks $(\mathrm{R}+\mathrm{UMB})$.

\begin{tabular}{|c|c|c|c|c|c|}
\hline Variable & $\mathbf{R}$ & R + SPVS & R + UMB & SEM & $p$-Value \\
\hline \multicolumn{6}{|c|}{ Daily intake $\left(\mathrm{g} / \mathrm{kg}^{0.75} \mathrm{LW}\right)$ and (share of supplement, $\left.\mathrm{g} / 100 \mathrm{~g}\right)$} \\
\hline DM & 70.9 & $76.0(19.3)$ & $66.8(1.7)$ & 3.08 & 0.170 \\
\hline $\mathrm{OM}$ & 63.1 & $67.5(19.0)$ & $59.0(1.0)$ & 2.79 & 0.158 \\
\hline NDF & 50.4 & $52.6(15.0)$ & $47.7(0.1)$ & 2.22 & 0.230 \\
\hline ADF & 32.3 & $33.9(17.0)$ & $30.2(0.1)$ & 1.30 & 0.311 \\
\hline $\mathrm{CP}$ & 5.6 & $6.7(30.5)$ & $5.5(7.7)$ & 0.31 & 0.113 \\
\hline \multicolumn{6}{|c|}{ Ingesta composition (g/kg DM) } \\
\hline $\mathrm{OM}$ & 890 & $887^{1}$ & 884 & 2.21 & 0.129 \\
\hline NDF & 709 & 691 & 715 & 9.31 & 0.122 \\
\hline $\mathrm{ADF}$ & 456 & 447 & 453 & 3.62 & 0.163 \\
\hline $\mathrm{CP}$ & $79^{a}$ & $88^{\mathrm{b}}$ & $82^{\mathrm{a}}$ & 0.21 & 0.040 \\
\hline \multicolumn{6}{|c|}{ Digestibility (g/kg) } \\
\hline $\mathrm{DM}$ & $474^{\mathrm{a}}$ & $510^{b}$ & $480^{a b}$ & 10.07 & 0.041 \\
\hline $\mathrm{OM}$ & $509^{\mathrm{A}}$ & $539^{B}$ & $512 \mathrm{AB}$ & 7.78 & 0.071 \\
\hline NDF & $496^{\mathrm{A}}$ & $530^{\mathrm{B}}$ & $506^{\mathrm{AB}}$ & 8.28 & 0.058 \\
\hline $\mathrm{ADF}$ & 428 & 458 & 429 & 6.79 & 0.134 \\
\hline
\end{tabular}

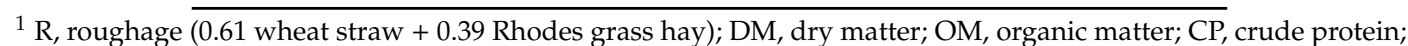
$\mathrm{NDF}$, neutral detergent fiber; ADF, acid detergent fiber; SEM, standard error of the mean; LW, live weight. $p$-values for independent variable diet obtained with PROC MIXED. Within rows, means with different lowercase superscripts differ at $p \leq 0.05$, means with different uppercase superscripts differ at $0.05<p \leq 0.10$ (Tukey post-hoc test). 
There were no differences in liquid and solid digesta passage parameters between diets or periods, respectively (Table 3). Spearman correlation analysis indicated that ingesta ADF concentration was negatively correlated (Table 4 ) with ruminal outflow rate $\lambda$ and positively correlated with CMRT of solid but not of liquid digesta. Quantitative intake (g/ $\left.\mathrm{kg}^{0.75} \mathrm{LW}\right)$ of DM, OM, CP, NDF, and ADF was positively related to $\lambda s$ and negatively to CMRTs and TMRTs. Furthermore, NDF and ADF digestibility showed a positive correlation with $\lambda s$ and a negative correlation with CMRTs, and TMRTs. Among the liquid digesta passage parameters, only TTl showed a negative correlation with OM as well as ADF digestibility (Table 4).

Table 3. Parameters of liquid $(l)$ and solid (s) digesta passage in heifers fed roughage (R) ${ }^{1}$ alone or supplemented with sweet potato vine silage $(\mathrm{R}+\mathrm{SPVS})$ or urea-molasses blocks $(\mathrm{R}+\mathrm{UMB})$.

\begin{tabular}{|c|c|c|c|c|c|}
\hline Variable & $\mathbf{R}$ & R + SPVS & R + UMB & SEM & $p$-Value \\
\hline \multicolumn{6}{|c|}{ Liquid digesta passage } \\
\hline$\lambda l(\% / \mathrm{h})$ & 9.2 & 9.2 & 9.0 & 0.43 & 0.972 \\
\hline $\mathrm{TTl}(\mathrm{h})$ & 4.3 & 3.1 & 4.4 & 0.39 & 0.230 \\
\hline CMRTl (h) & 22.0 & 22.0 & 23.2 & 1.08 & 0.854 \\
\hline TMRTl (h) & 26.3 & 25.0 & 27.6 & 0.97 & 0.567 \\
\hline \multicolumn{6}{|c|}{ Solid digesta passage } \\
\hline$\lambda s(\% / \mathrm{h})$ & 3.5 & 3.8 & 3.4 & 0.14 & 0.262 \\
\hline $\mathrm{TTs}(\mathrm{h})$ & 18.9 & 16.8 & 16.2 & 0.77 & 0.368 \\
\hline CMRTs (h) & 56.8 & 54.4 & 60.2 & 2.08 & 0.298 \\
\hline TMRTs (h) & 75.8 & 71.2 & 76.4 & 2.08 & 0.460 \\
\hline
\end{tabular}

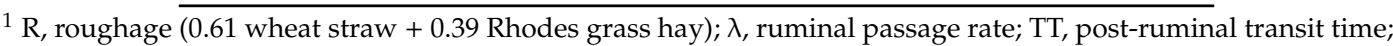
CMRT, retention time in the rumen; TMRT, retention time in total gastrointestinal tract; SEM, standard error of the mean. $p$-values for independent variable diet obtained with PROC MIXED. 
Table 4. Spearman correlation coefficients $\left(\mathrm{r}_{\mathrm{s}}\right)$ and significance levels ${ }^{1}$ of the individual relationships between quantitative intake, ingesta concentration and digestibility of organic matter (OM), crude protein (CP), neutral detergent fiber (NDF), acid detergent fiber (ADF), duodenal microbial nitrogen (N) flow, and efficiency of rumen microbial protein synthesis (EMPS) with liquid $(l)$ and solid $(s)$ ruminal passage rate $(\lambda)$, post ruminal transit time (TT), rumen retention time (CMRT) and total tract retention time (TMRT) in heifers fed with roughage alone or supplemented with sweet potato vine silage and urea-molasses blocks.

\begin{tabular}{|c|c|c|c|c|c|c|c|c|c|c|c|c|c|c|c|c|}
\hline \multirow{3}{*}{$\begin{array}{l}\text { Variable } \\
\text { Feed intake }\left(\mathrm{g} / \mathrm{kg}^{0.75} \mathrm{LW}\right)\end{array}$} & \multicolumn{8}{|c|}{ Liquid Digesta Passage } & \multicolumn{8}{|c|}{ Solid Digesta Passage } \\
\hline & \multicolumn{2}{|c|}{$\lambda l(\% / \mathrm{h})$} & \multicolumn{2}{|c|}{ TTl (h) } & \multicolumn{2}{|c|}{ CMRTl (h) } & \multicolumn{2}{|c|}{ TMRT $l$ (h) } & \multicolumn{2}{|c|}{$\lambda s(\% / h)$} & \multicolumn{2}{|c|}{ TTs (h) } & \multicolumn{2}{|c|}{ CMRTs (h) } & \multicolumn{2}{|c|}{ TMRTs (h) } \\
\hline & & & & & & & & & & & & & & & & \\
\hline $\mathrm{OM}$ & 0.29 & n.s. & -0.36 & n.s. & -0.29 & n.s. & -0.57 & $(*)$ & 0.92 & $* * *$ & 0.45 & n.s. & -0.92 & $* * *$ & -0.75 & $* *$ \\
\hline $\mathrm{CP}$ & 0.42 & n.s. & -0.26 & n.s. & -0.42 & n.s. & -0.69 & * & 0.82 & $* *$ & 0.31 & n.s. & -0.82 & $* *$ & -0.66 & * \\
\hline NDF & 0.29 & n.s. & -0.29 & n.s. & -0.29 & n.s. & -0.52 & $(*)$ & 0.95 & $* * *$ & 0.48 & n.s. & -0.95 & $* * *$ & -0.78 & $* *$ \\
\hline $\mathrm{ADF}$ & 0.31 & n.s. & -0.36 & n.s. & -0.31 & n.s. & -0.60 & * & 0.91 & $* * *$ & 0.45 & n.s. & -0.91 & $* * *$ & -0.74 & $* *$ \\
\hline \multicolumn{17}{|l|}{$\begin{array}{l}\text { Ingesta composition } \\
(\mathrm{g} / \mathrm{kg} \mathrm{DM})\end{array}$} \\
\hline $\mathrm{OM}$ & -0.26 & n.s. & -0.31 & n.s. & 0.26 & n.s. & 0.05 & n.s. & 0.45 & n.s. & 0.57 & $(*)$ & -0.45 & n.s. & -0.33 & n.s. \\
\hline $\mathrm{CP}$ & 0.25 & n.s. & -0.20 & n.s. & -0.25 & n.s. & -0.48 & n.s. & 0.31 & n.s. & -0.15 & n.s. & -0.31 & n.s. & -0.30 & n.s. \\
\hline NDF & -0.14 & n.s. & -0.06 & n.s. & 0.14 & n.s. & 0.21 & n.s. & 0.21 & n.s. & 0.08 & n.s. & -0.21 & n.s. & -0.21 & n.s. \\
\hline $\mathrm{ADF}$ & -0.55 & $(*)$ & 0.07 & n.s. & 0.55 & $(*)$ & 0.65 & $*$ & -0.70 & $*$ & -0.19 & n.s. & 0.70 & $*$ & 0.57 & $(*)$ \\
\hline \multicolumn{17}{|l|}{ Digestibility (g/kg) } \\
\hline $\mathrm{DM}$ & 0.13 & n.s. & -0.62 & $*$ & -0.13 & n.s. & -0.41 & n.s. & 0.65 & $*$ & -0.10 & n.s. & -0.65 & * & -0.73 & $* *$ \\
\hline $\mathrm{OM}$ & 0.00 & n.s. & -0.70 & * & 0.00 & n.s. & -0.31 & n.s. & 0.45 & n.s. & -0.17 & n.s. & -0.45 & n.s. & -0.55 & $\left({ }^{*}\right)$ \\
\hline NDF & 0.20 & n.s. & -0.55 & $(*)$ & -0.20 & n.s. & -0.43 & n.s. & 0.64 & $*$ & -0.11 & n.s. & -0.64 & $*$ & -0.76 & $* *$ \\
\hline $\mathrm{ADF}$ & 0.10 & n.s. & -0.69 & $*$ & -0.10 & n.s. & -0.37 & n.s. & 0.68 & * & -0.02 & n.s. & -0.68 & $*$ & -0.76 & $* *$ \\
\hline $\begin{array}{l}\text { Duodenal microbial N } \\
\text { flow (g N/day) }\end{array}$ & 0.66 & $*$ & -0.04 & n.s. & -0.66 & * & -0.76 & $* *$ & 0.48 & n.s. & 0.00 & n.s. & -0.48 & n.s. & -0.53 & $(*)$ \\
\hline \multicolumn{17}{|l|}{ EMPS } \\
\hline (g N/kg OM intake) & 0.42 & n.s. & 0.09 & n.s. & -0.42 & n.s. & -0.39 & n.s. & 0.01 & n.s. & -0.02 & n.s. & -0.01 & n.s. & -0.07 & n.s. \\
\hline$(\mathrm{g} \mathrm{N} / \mathrm{kg} \mathrm{dOM})$ & 0.42 & n.s. & 0.09 & n.s. & -0.42 & n.s. & -0.39 & n.s. & 0.01 & n.s. & -0.02 & n.s. & -0.01 & n.s. & -0.07 & n.s. \\
\hline (g N/g N intake) & 0.28 & n.s. & -0.01 & n.s. & -0.28 & n.s. & -0.21 & n.s. & -0.03 & n.s. & 0.06 & n.s. & 0.03 & n.s. & -0.06 & n.s. \\
\hline
\end{tabular}

$\mathrm{DM}$, dry matter; OM, organic matter; dOM, digested OM; CP, crude protein; N, nitrogen; NDF, neutral detergent fiber; ADF, acid detergent fiber; LW, live weight; EMPS, efficiency of microbial protein synthesis, Significance levels, n.s. non-significant $\left(^{*}\right) p \leq 0.10,{ }^{*} p \leq 0.05,{ }^{* *} p \leq 0.01,{ }^{* * *} p \leq 0.001$. 


\subsection{Nitrogen Balance and Efficiency of Microbial Protein Synthesis}

Nitrogen intake with $\mathrm{R}+$ SPVS was $20 \%$ higher than with $\mathrm{R}$ and $\mathrm{R}+\mathrm{UMB}$, due to higher ingesta $\mathrm{CP}$ (and hence $\mathrm{N}$ ) concentration $(p=0.04)$. However, diet had no effect on microbial $\mathrm{N}$ flow, the efficiency of its synthesis (EMPS) and $\mathrm{N}$ balance (Table 5). Nitrogen retention was negative for all treatments but tended to be highest with $\mathrm{R}+\mathrm{SPVS}(p=0.051)$. This was in line with daily LW losses of $-0.50,-0.25$, and $-0.30 \mathrm{~kg} / \mathrm{d}$ for $\mathrm{R}, \mathrm{R}+\mathrm{SPVS}$, and $\mathrm{R}+\mathrm{UMB}$ across the two periods (data not shown). Concentration of total PD and creatinine in urine, total PD excretion, and duodenal microbial $\mathrm{N}$ flow (Table 5) were highest in $\mathrm{R}+$ SPVS $(p>0.10)$. Microbial $\mathrm{N}$ flow correlated positively with $\lambda l$ and negatively with CMRTl and TMRTl (Table 4). There was no effect of experimental period on $\mathrm{N}$ balance and microbial protein synthesis.

Table 5. Nitrogen (N) balance, excretion of purine derivatives (PD), duodenal microbial N flow, and efficiency of rumen microbial protein synthesis (EMPS) in heifers fed with roughage (R) ${ }^{1}$ alone or supplemented with sweet potato vine silage $(\mathrm{R}+\mathrm{SPVS})$ and urea-molasses blocks $(\mathrm{R}+\mathrm{UMB})$.

\begin{tabular}{lccccc}
\hline \multicolumn{1}{c}{ Variable } & $\mathbf{R}$ & $\mathbf{R}+$ SPVS & $\mathbf{R}+$ UMB & SEM & $p$ Value \\
\hline Nitrogen balance $\left(\mathrm{g} / \mathrm{kg}^{0.75}\right.$ & $\mathrm{LW})$ & & & & \\
$\quad$ N intake & 0.90 & 1.08 & 0.88 & 0.050 & 0.113 \\
Fecal N excretion & 0.60 & 0.65 & 0.60 & 0.028 & 0.367 \\
Urine N excretion & 0.45 & 0.48 & 0.45 & 0.026 & 0.655 \\
& -0.15 & & & & \\
N retention & $\mathrm{A}$ & -0.05 & -0.17 & 0.021 & 0.051 \\
Fecal-to-urine N ratio & 1.33 & 1.44 & 1.32 & 0.066 & 0.576 \\
Urine PD excretion (mmol/day) & & & & \\
Allantoin & 35.62 & 40.55 & 29.62 & 2.524 & 0.281 \\
Uric acid & 7.21 & 9.87 & 6.07 & 0.849 & 0.324 \\
$\quad$ Xanthine + & & & & & \\
hypoxanthine & 0.03 & 0.06 & 0.02 & 0.006 & 0.150 \\
$\quad$ Total PD excretion & 42.86 & 50.48 & 35.72 & 3.274 & 0.283 \\
Creatinine (mmol/day) & 29.66 & 33.63 & 25.70 & 1.357 & 0.452 \\
PD-to-creatinine ratio & 1.45 & 1.50 & 1.38 & 0.078 & 0.572 \\
Duodenal microbial N & 27.73 & 33.95 & 21.85 & 2.696 & 0.512 \\
flow (g/day) & & & & & \\
EMPS & & & & & \\
$\quad$ (g N/kg OM intake) & 10.23 & 11.63 & 8.76 & 0.849 & 0.139 \\
(g N/kg dOM) & 20.20 & 21.61 & 16.98 & 1.601 & 0.617 \\
(g N/g N intake) & 0.71 & 0.73 & 0.59 & 0.052 & 0.126 \\
\hline
\end{tabular}

${ }^{1} \mathrm{R}$, roughage (wheat straw + Rhodes grass hay); LW, live weight; OM, Organic matter; dOM, digested OM; SEM, Standard error of the mean. $p$-values for independent variable diet obtained with PROC MIXED. Within rows, means with different uppercase superscript differ at $0.05<p \leq 0.01$ (Tukey post-hoc test).

\subsection{Methane Emissions}

There was no difference between diets when relating $\mathrm{CH}_{4}$ emission to feed intake (Table 6), irrespective of the constituent (i.e., DM, OM, NDF, and ADF). Methane emission per unit of digested (d) DM (dDM) was lower in $\mathrm{R}+$ SPVS than in $\mathrm{R}(p=0.041)$ but similar to $\mathrm{R}+\mathrm{UMB}$. In addition, there was a tendency $(p=0.09)$ towards lower $\mathrm{CH}_{4}$ emission per unit of dOM in $\mathrm{R}+$ SPVS (Table 6), whereas $\mathrm{CH}_{4}$ emitted per unit of $\mathrm{dNDF}$ and $\mathrm{dADF}$ was only numerically lower for $\mathrm{R}+\mathrm{SPVS}$ than for the other diets $(p>0.10)$. Daily emission ( $\mathrm{g} \mathrm{CH}_{4} /$ animal-day) correlated significantly with liquid digesta passage parameters $\lambda l$, CMRTl and TMRTl (Table 7), as well as with TMRTs, whereas for $\lambda s$ and CMRTs there was only a weak correlation $\left(\mathrm{r}_{\mathrm{s}}<0.56\right)$. In contrast, $\mathrm{CH}_{4}$ yield, that is $\mathrm{g} \mathrm{CH}_{4}$ per $\mathrm{kg}$ DMI, strongly correlated with solid digesta passage parameters ( $\lambda s, \mathrm{CMRT} s, \mathrm{TMRT} s)$. A significant correlation with solid digesta passage parameters also existed for $\mathrm{CH}_{4}$ emitted per unit of ingested $\mathrm{OM}$ and NDF, and for $\mathrm{CH}_{4}$ emitted per unit of dDM, dOM, and dNDF (Table 7). Increasing DMI increased daily $\mathrm{CH}_{4}$ emission $\left(\mathrm{R}^{2}=0.62, p=0.003\right)$ but decreased $\mathrm{CH}_{4}$ yield $\left(\mathrm{R}^{2}=-0.68, p=0.008\right)$. 
Table 6. Methane $\left(\mathrm{CH}_{4}\right)$ emissions by heifers fed with roughage (R) ${ }^{1}$ alone or supplemented with sweet potato vine silage $(R+S P V S)$ or urea-molasses blocks $(R+U M B)$.

\begin{tabular}{lccccc}
\hline Methane (g) Emitted & $\mathbf{R}$ & $\mathbf{R}+$ SPVS & $\mathbf{R}+$ UMB & SEM & $p$-value \\
\hline /animal-day & 93.1 & 92.4 & 85.3 & 3.00 & 0.611 \\
/kg DMI & 30.6 & 28.1 & 30.6 & 0.85 & 0.240 \\
/kg OMI & 34.4 & 31.7 & 34.6 & 0.99 & 0.238 \\
/kg NDFI & 43.2 & 40.8 & 42.7 & 1.33 & 0.538 \\
/kg ADFI & 67.0 & 62.9 & 67.4 & 1.76 & 0.395 \\
/kg dDM & $64.7^{\mathrm{b}}$ & $55.2^{\mathrm{a}}$ & $63.8^{\mathrm{ab}}$ & 2.33 & 0.041 \\
/kg dOM & $67.8^{\mathrm{B}}$ & $58.9^{\mathrm{A}}$ & $67.5^{\mathrm{B}}$ & 2.28 & 0.094 \\
/kg dNDF & 88.1 & 77.0 & 84.6 & 3.52 & 0.167 \\
/kg dADF & 157.5 & 137.7 & 157.1 & 5.40 & 0.133 \\
\hline
\end{tabular}

${ }^{1} \mathrm{R}$, roughage (0.61 wheat straw + 0.39 Rhodes grass hay); DM, dry matter; OM, organic matter; NDF, neutral detergent fiber; $\mathrm{ADF}$, acid detergent fiber; DMI, DM intake; OMI, OM intake; NDFI, NDF intake; ADFI, ADF intake; dDM, digested DM; dOM, digested OM; dNDF, digested NDF; dADF, digested ADF; SEM, standard error of the mean. $p$-values for independent variable diet obtained with PROC MIXED. Within rows, means with different lowercase superscripts differ at $p \leq 0.05$; means with different uppercase superscripts differ at $0.05<p \leq 0.01$ (Tukey post-hoc test)

Table 7. Spearman correlation coefficients $\left(\mathrm{r}_{\mathrm{s}}\right)$ and significance levels ${ }^{1}$ of the relationship between liquid $(l)$ and solid $(s)$ digesta passage parameters and the emission of methane in heifers fed with roughage alone or supplemented with sweet potato vine silage or urea-molasses blocks.

\begin{tabular}{|c|c|c|c|c|c|c|c|c|c|c|c|c|c|c|}
\hline \multirow{2}{*}{ Parameter } & \multicolumn{14}{|c|}{ Methane (g) emitted } \\
\hline & \multicolumn{2}{|c|}{ /Animal-Day } & \multicolumn{2}{|c|}{ /kg DMI } & \multicolumn{2}{|c|}{$/$ kg OMI } & \multicolumn{2}{|c|}{$/$ kg NDFI } & \multicolumn{2}{|c|}{$/ \mathrm{kg}$ dDM } & \multicolumn{2}{|c|}{$/ \mathrm{kg} \mathrm{dOM}$} & \multicolumn{2}{|c|}{$/ \mathrm{kg}$ dNDF } \\
\hline & & & & & & & & & & & & & & \\
\hline$\lambda l(\% / \mathrm{h})$ & 0.78 & $* *$ & -0.13 & n.s. & -0.15 & n.s. & -0.15 & n.s. & -0.14 & n.s. & -0.06 & n.s. & -0.16 & n.s. \\
\hline $\mathrm{TT} l(\mathrm{~h})$ & 0.20 & n.s. & 0.39 & n.s. & 0.34 & n.s. & 0.39 & n.s. & 0.54 & $(*)$ & 0.57 & $(*)$ & 0.52 & $(*)$ \\
\hline TMRTl (h) & -0.84 & $* * *$ & 0.40 & n.s. & 0.41 & n.s. & 0.41 & n.s. & 0.43 & n.s. & 0.36 & n.s. & 0.43 & n.s. \\
\hline $\begin{array}{l}\text { Solid digesta } \\
\text { passage }\end{array}$ & & & & & & & & & & & & & & \\
\hline$\lambda s(\% / \mathrm{h})$ & 0.55 & $(*)$ & -0.90 & $* * *$ & -0.91 & $* * *$ & -0.90 & $* * *$ & -0.84 & $* * *$ & -0.81 & ** & -0.83 & $* * *$ \\
\hline TTs (h) & 0.03 & n.s. & -0.41 & n.s. & -0.40 & n.s. & -0.28 & n.s. & -0.16 & n.s. & -0.22 & n.s. & -0.04 & n.s. \\
\hline TMRTs (h) & -0.62 & $*$ & 0.68 & . & 0.70 & * & 0.75 & $* *$ & 0.76 & $* *$ & 0.67 & $*$ & 0.84 & $* * *$ \\
\hline
\end{tabular}

${ }^{1}$ Significance levels: n.s., not significant, $\left(^{*}\right) p \leq 0.10,{ }^{*} p \leq 0.05,{ }^{* *} p \leq 0.01,{ }^{* * *} p \leq 0.001$; DMI, dry matter intake; OMI, organic matter intake; NDFI, neutral detergent fiber intake; $\mathrm{dDM}$, digested dry matter; $\mathrm{dOM}$, digested organic matter; $\mathrm{dNDF}$, digested NDF; $\lambda$, ruminal passage rate, TT, post ruminal transit time; TMRT, retention time in total gastrointestinal tract.

\section{Discussion}

\subsection{Supplementation Effects on Intake, Digestibility, and Digesta Passage}

Supplementation of SPVS and UMB to the roughage had no effect on feed intake, despite lower NDF and $\mathrm{ADF}$ and higher $\mathrm{CP}$ concentrations in both supplements, and only SPVS supplementation increased ingesta CP concentration. The lack of intake improvement through SPVS and UMB supplementation might be explained by a limited improvement of feed degradation in the rumen as the basal diet (R) already contained $79 \mathrm{~g} \mathrm{CP} / \mathrm{kg}$ DM. Similar DM and OM intakes of basal and supplemented diet were also reported by Piñeiro-Vázquez et al. [12] for heifers on P. purpureum (71 g CP, $659 \mathrm{~g}$ NDF per kg DM) supplemented with Leucaena leucocephala. However, at lower CP concentrations of the basal diet, an increased intake and digestibility (of $\mathrm{DM}, \mathrm{OM}, \mathrm{CP}, \mathrm{NDF}$, and $\mathrm{ADF}$ ) was observed in growing goats feeding on Ischaemum aristatum ( $68 \mathrm{~g} \mathrm{CP}, 396 \mathrm{~g}$ NDF per $\mathrm{kg} \mathrm{DM}$ ) and supplemented with fresh sweet potato vine [35], and in Boran steers fed wheat straw (20 g CP, $807 \mathrm{~g}$ NDF per $\mathrm{kg} \mathrm{DM}$ ) supplemented with Calliandra calothyrsus leaves [36].

The CP concentration in the present SPVS was within the range of $\mathrm{CP}$ concentrations in leaves and stems of 15 sweet potato varieties from Vietnam [14], but higher than reported from Nigeria [18], 
and lower than reported from Ethiopia [16] and Kenya [15]. Present NDF and ADF concentrations of SPVS were higher than reported by these four studies. Such differences in SPVS composition might be due to differences in variety, stage of growth, harvest season, and way of silage preparation.

Higher CP and lower NDF and ADF concentrations in ingesta of $R+$ SPVS as compared to R and $\mathrm{R}+\mathrm{UMB}$ improved $\mathrm{dDM}$ and by trend also dOM and $\mathrm{dNDF}$, but had no effect on dADF. The lack of effects of UMB supplementation on digestibility of diet constituents might be partly explained by its low daily intake that averaged $51 \mathrm{~g}$ DM ( \pm 11.0$)$, equivalent to $1.8 \mathrm{~g}$ DM per $100 \mathrm{~g}$ DMI and $8.3 \mathrm{~g} \mathrm{~N}$ per $100 \mathrm{~g} \mathrm{~N}$ intake. Difficulties in the exact determination of daily UMB intake were encountered, even though an unused lick block served as reference to account for weight differences in the hygroscopic material due to changing air humidity.

No significant correlation was found between liquid digesta passage parameters and intake. However, increasing intake increased the hourly outflow of particles from the rumen $(\lambda s)$ and reduced rumen and total tract retention time of solid digesta (CMRTs, TMRTs). In contrast to this, Mlay et al. [37] reported that passage rate of particles was not modified by increasing intake of heifers fed hay and supplemented with either urea or soybean cake. The fact that $\lambda l$ was not related to feed intake in the present experiment may be due to the high NDF concentration of ingesta: for cattle on fiber-rich diets, Das and Singh [38] observed higher rumen solid and liquid contents and a higher DM pool size with increasing DMI due to supplementation. Moreover, dietary fiber content positively correlates with its water-holding capacity and increases liquid volume in the rumen [39].

\subsection{Supplementation Effects on Nitrogen Balance and Microbial Protein Synthesis}

There was a tendency towards higher $\mathrm{N}$ retention in heifers consuming $\mathrm{R}+\mathrm{SPVS}$, due to higher ingesta $\mathrm{N}$ concentration and greater DM digestibility. Several studies reported high protein quality of sweet potato leaves, with a good $\mathrm{N}$ solubility and with essential amino acids accounting for $40.7 \%$ of total CP [40,41]. Even though $\mathrm{N}$ balance was negative in the present study, its improvement through SPVS supplementation agrees with reports on higher $\mathrm{N}$ intake and retention in Boran steers fed wheat straw supplemented with C. calothyrsus as compared to a pure wheat straw diet [36]. Improved N balance and higher LW gain was also obtained for cattle on wheat straw supplemented with UMB [8]. Piñeiro-Vázquez et al. [12] reported that increasing legume supplementation increased $\mathrm{N}$ intake and $\mathrm{N}$ retention of heifers despite higher urine $\mathrm{N}$ excretion and similar fecal $\mathrm{N}$ excretion. An improved $\mathrm{N}$ balance along with higher rumen ammonia and total VFA concentrations and a higher yield of bacteria per mol ATP was reported for cattle on wheat straw supplemented with three different UMB formulas [22]. Abdulrazak et al. [42] found that urine PD excretion ranged from 68.6 to $81.9 \mathrm{mmol} / \mathrm{day}$ in grass-fed steers and increased with legume supplementation, but microbial $\mathrm{N}$ flow to the duodenum and EMPS remained unaffected. In contrast, urine PD excretion of Boran steers on wheat straw supplemented with C. calothyrsus was only 7.9-13.6 mmol per $100 \mathrm{~kg}$ LW [36] and thus lower than the present average values (28, 32, and $25 \mathrm{mmol}$ per $100 \mathrm{~kg} \mathrm{LW}$ for $\mathrm{R}, \mathrm{R}+\mathrm{SPVS}$, and R + UMB). Furthermore, for all diets tested in the current study, EMPS per unit of dOM (16.98-21.61 g N/kg $\mathrm{dOM})$ was higher than the values $(-3.00-1.75 \mathrm{~g} \mathrm{~N} / \mathrm{kg} \mathrm{dOM})$ reported for the Boran steers [36]. The lack of differences in PD excretion and thus microbial $\mathrm{N}$ flow between the tested diets agrees with findings of Phesatcha and Wanapat [19] for a diet of urea-treated rice straw with or without concentrate supplementation, even though their absolute values of PD excretion (165-179 $\mathrm{mmol} /$ day) were higher than the present ones (36-50 $\mathrm{mmol} /$ day).

The $7 \%$ higher outflow rate of solids $(\lambda s)$ with $R+$ SPVS as compared to R likely reduced the proportion of feed nutrients fermented in the rumen and thus counteracted the increased substrate supply to rumen microbes due to higher feed intake and digestibility. In this line, faster rumen passage of solid digesta might have increased the availability of undegraded feed $\mathrm{CP}$ for post-ruminal digestion and absorption by the host animal and thus $\mathrm{N}$ retention. An increase of duodenal microbial $\mathrm{N}$ flow with greater feed intake is reflected by the correlation between microbial $\mathrm{N}$ flow and $\lambda l$ as well as CMRT $l$, while the absence of differences in microbial $\mathrm{N}$ flow and EMPS between the three diets indicates that 
SPVS and UMB supplementation did not enhance microbial growth in the rumen. This might in part be explained by a sufficiency of rumen degradable protein at a DM concentration of $7.9 \% \mathrm{CP}$ in the roughage [24,43].

\subsection{Supplementation Effects on Enteric Methane Emissions}

Across diets, $\mathrm{CH}_{4}$ yield was within the range of 25.7-31.9 $\mathrm{g} \mathrm{CH}_{4} / \mathrm{kg}$ DMI determined in Holstein cows fed a mixed alfalfa/corn silage [44]. Present $\mathrm{CH}_{4}$ yields were however greater than the 17.3-22.4 $\mathrm{g}$ $\mathrm{CH}_{4} / \mathrm{kg}$ DMI determined for steers fed tropical grasses ad libitum [45], and the $22.6 \mathrm{~g} \mathrm{CH}_{4} / \mathrm{kg}$ DMI reported for Holstein steers on barley silage and steam-rolled barley [46]. Increasing DMI (kg/day) increased $\mathrm{CH}_{4}$ emission ( $\mathrm{g} \mathrm{CH}_{4}$ /animal-day) and decreased $\mathrm{CH}_{4}$ yield (Figure 1), illustrating the influence of feed intake on energy loss via $\mathrm{CH}_{4}$. Reduced $\mathrm{CH}_{4}$ yields were also reported for tropical [47] and temperate [48] forages and cattle breeds when intake increased.
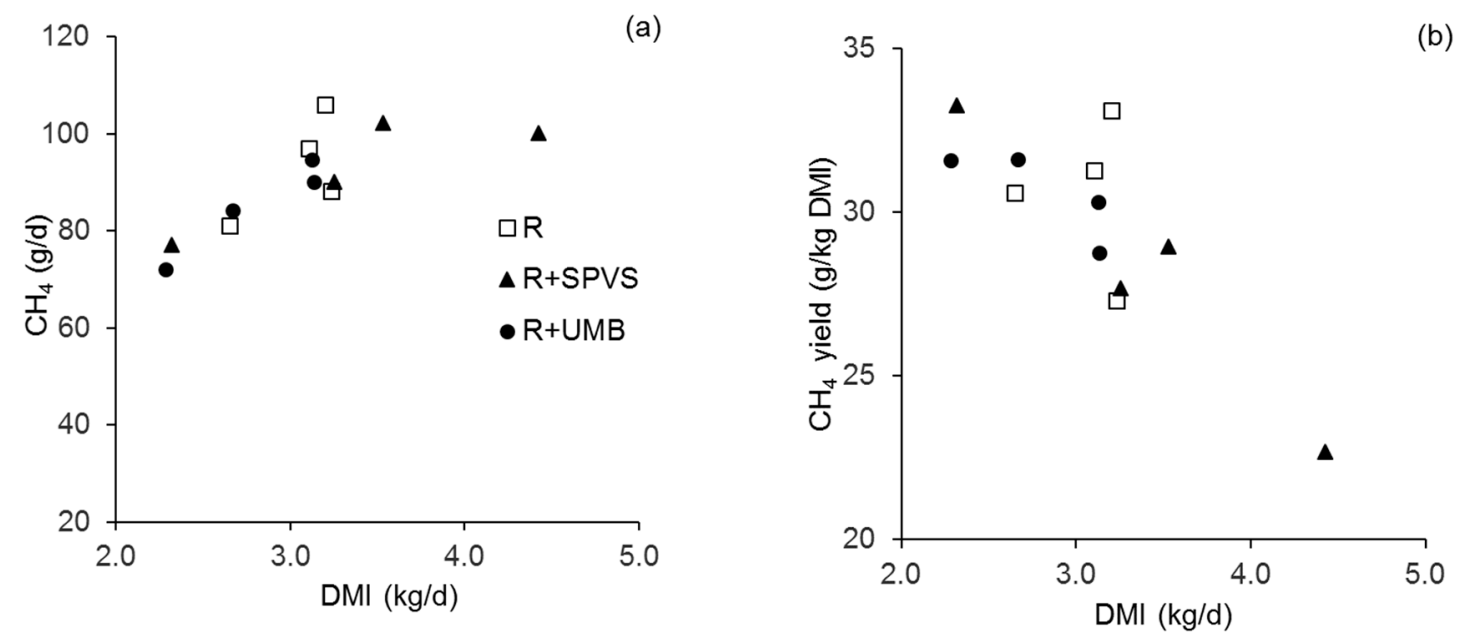

Figure 1. Relationship of the animals' daily dry matter intake (DMI) to: (a) methane $\left(\mathrm{CH}_{4}\right)$ emissions $\left(\mathrm{R}^{2}=0.62\right)$; and $(\mathbf{b}) \mathrm{CH}_{4}$ yield $\left(\mathrm{R}^{2}=0.68\right)$. The legend in (a) also applies to $(\mathbf{b})$. $\mathrm{R}$, roughage $(0.61$ wheat straw + 0.39 Rhodes grass hay); SPVS, sweet potato vine silage: UMB, urea-molasses block; DMI, dry matter intake.

Generally, $\mathrm{CH}_{4}$ yield positively correlates with dietary fiber concentration due to greater hydrogen yields when higher proportions of acetate are formed in the rumen [10,49]. The high NDF and ADF concentrations in diets $\mathrm{R}$ and $\mathrm{R}+\mathrm{UMB}$ increased rumen retention time of particles $[50,51]$, thereby prolonging time available for $\mathrm{CH}_{4}$ formation [49]. Present $\mathrm{CH}_{4}$ emission only correlated with $\mathrm{\lambda l}$ but not with any other digesta passage parameter. Goopy et al. [52] also reported that $\mathrm{CH}_{4}$ yield was more strongly associated with CMRTl $\left(R^{2}=0.69\right)$ than with CMRTs $\left(R^{2}=0.56\right)$. In sheep fed several levels of ryegrass, differences in $\mathrm{CH}_{4}$ yield were better explained by $\lambda l$ than by $\lambda$, because quantitative intake had a stronger effect on rumen passage of liquid than of solid digesta, with increasing intake decreasing CMRTl, CMRTs, TMRTl, and TMRTs as well as $\mathrm{CH}_{4}$ yield [48]. Likewise, in the present study, increasing intake decreased CMRTs, TMRTs and $\mathrm{CH}_{4}$ yield. The significant relationship between $\lambda s$ and CMRTs with $\mathrm{CH}_{4}$ per unit of DMI and dDM underlines the strong dependency of enteric $\mathrm{CH}_{4}$ formation on rumen digesta kinetics.

A certain potential for $\mathrm{CH}_{4}$ mitigation by upgrading a poor-quality roughage diet was demonstrated for SPVS supplementation, which reduced $\mathrm{CH}_{4}$ emission per unit dDM. Although SPVS supplementation only slightly improved dDM and had a significant effect on neither rumen microbial protein synthesis (indicator for the activity of rumen bacteria [33]) nor on the ruminal passage rate of solid digesta $(\lambda s)$, the respective values were numerically higher for $R+$ SPVS than for R and $R+U M B$. The absence of effects of UMB supplementation might be due to the low UMB intake as discussed above. The slight increase in $\mathrm{N}$ intake with $\mathrm{R}+\mathrm{SPVS}$ improved the animals' $\mathrm{N}$ retention with no 
decrease of $\mathrm{N}$ excretion via feces and urine. The latter points to an excess of rumen ammonia in the SPVS diet which should be balanced by supplying additional energy $[23,24]$. The unchanged nitrogen excretion in the present study also indicates that an evaluation of feeding strategies that mitigate greenhouse gas emissions from ruminants should also consider if and how a reduction of enteric $\mathrm{CH}_{4}$ formation affects emissions from excreta, such as nitrous oxide and ammonia [53,54].

\section{Conclusions}

SPVS and UMB supplementation of poor quality roughage did not improve feed intake of Holstein $\times$ Boran heifers. However, enhanced ingesta CP content with SPVS supplementation improved feed digestibility and reduced formation of enteric $\mathrm{CH}_{4}$ per unit of dDM. Neither supplement enhanced the efficiency of microbial protein synthesis, but SPVS decreased rumen retention time of solid digesta and positively affected $\mathrm{N}$ balance. Therefore, supplementing cattle on poor quality roughage with SPVS has the potential to improve diet digestibility, $\mathrm{N}$ retention, and mitigate greenhouse gas emissions in tropical smallholder systems, in particular in the end of the dry season when forages are scarce and fibrous.

Author Contributions: Conceptualization, L.M. and J.P.G.; Data curation, A.I.M.A., S.E.W. and D.K.; Funding acquisition, K.B.-B.; Investigation, A.I.M.A., S.E.W. and D.K.; Methodology, J.P.G. and U.D.; Project administration, L.M.; Supervision, L.M., J.P.G., K.B.-B., U.D. and E.S.; Writing-original draft, A.I.M.A. and S.E.W.; and Writing-review and editing, D.K., L.M., J.P.G., K.B.-B., U.D. and E.S.

Funding: This research was funded by German Federal Ministry for Economic Cooperation and Development, grant number 5521914.

Acknowledgments: We are grateful to Herrmann Baumgaertner for carrying out the laboratory analysis, to Eva Wiegard and Claudia Thieme for preparing the marked fiber, and to Stanley Mwangi and Titis Apdini for assisting with the experiment and sample collection. Lutz Merbold, John P. Goopy, Klaus Butterbach-Bahl and Daniel Korir further acknowledge the Consultative Group on International Agricultural Research (CGIAR) Fund Council, Australia (ACIAR), Irish Aid, European Union, International Fund for Agricultural Development (IFAD), Netherlands, New Zealand, UK, USAID and Thailand for funding to the CGIAR Research Program on Climate Change, Agriculture and Food Security (CCAFS) and the CGIAR Research Program on Livestock.

Conflicts of Interest: The authors declare no conflict of interest.

\section{References}

1. Duncan, A.J.; Tarawali, S.A.; Thorne, P.J.; Valbuena, D.; Descheemaeker, K.; Homann-Kee Tui, S. Integrated crop-livestock systems-A key to sustainable intensification in Africa. Trop. Grassl. 2013, 1, $202-206$. [CrossRef]

2. Valbuena, D.; Erenstein, O.; Homann-Kee Tui, S.; Abdoulaye, T.; Claessens, L.; Duncan, A.J.; Gérard, B.; Rufino, M.C.; Teufel, N.; van Rooyen, A.; et al. Conservation agriculture in mixed crop-livestock systems: Scoping crop residue trade-offs in sub-Saharan Africa and South Asia. Field Crops Res. 2012, 132, 175-184. [CrossRef]

3. Nyaata, O.Z.; Dorward, P.T.; Keatinge, J.D.H.; O’Neill, M.K. Availability and use of dry season feed resources on smallholder dairy farms in central Kenya. Agroforest. Syst. 2000, 50, 315-331. [CrossRef]

4. Goopy, J.P.; Onyango, A.A.; Dickhoefer, U.; Butterbach-Bahl, K. A new approach for improving emission factors for enteric methane emissions of cattle in smallholder systems of East Africa-Results for Nyando, Western Kenya. Agric. Syst. 2018, 161, 72-80. [CrossRef]

5. Otte, M.J.; Chilonda, P. Cattle and Small Ruminant Production Systems in Sub-Saharan Africa; FAO: Rome, Italy, 2002.

6. Koralagama, K.D.N.; Mould, F.L.; Fernandez-Rivera, S.; Hanson, J. The effect of supplementing maize stover with cowpea (Vigna unguiculata) haulms on the intake and growth performance of Ethiopian sheep. Animal 2008, 2, 954-961. [CrossRef]

7. Abdou, N.; Nsahlai, I.V.; Chimonyo, M. Effects of groundnut haulms supplementation on millet stover intake; digestibility and growth performance of lambs. Anim. Feed Sci. Technol. 2011, 169, 176-184. [CrossRef]

8. Garg, M.R.; Gupta, B.N. Effect of supplementing urea molasses mineral block lick to straw based diet on DM intake and nutrient utilization. Asian Australas. J. Anim. Sci. 1992, 5, 39-44. [CrossRef] 
9. Van Soest, P.J. Rice straw, the role of silica and treatments to improve quality. Anim. Feed Sci. Technol. 2006, 130, 137-171. [CrossRef]

10. Archimède, H.; Eugène, M.; Marie Magdeleine, C.; Boval, M.; Martin, C.; Morgavi, D.P.; Lecomte, P.; Doreau, M. Comparison of methane production between C3 and C4 grasses and legumes. Anim. Feed Sci. Technol. 2011, 166-167, 59-64. [CrossRef]

11. Kurihara, M.; Magner, T.; Hunter, R.A.; McCrabb, G.J. Methane production and energy partition of cattle in the tropics. Br. J. Nutr. 1999, 81, 227-234. [CrossRef]

12. Piñeiro-Vázquez, A.T.; Jiménez-Ferrer, G.O.; Chay-Canul, A.J.; Casanova-Lugo, F.; Díaz-Echeverría, V.F.; Ayala-Burgos, A.J.; Solorio-Sánchez, F.J.; Aguilar-Pérez, C.F.; Ku-Vera, J.C. Intake; digestibility; nitrogen balance and energy utilization in heifers fed low-quality forage and Leucaena leucocephala. Anim. Feed Sci. Technol. 2017, 228, 194-201. [CrossRef]

13. Umunna, N.N.; Osuji, P.O.; Nsahlai, I.V.; Khalili, H.; Mohamed-Saleem, M.A. Effect of supplementing oat hay with lablab, sesbania, tagasaste or wheat middlings on voluntary intake, $\mathrm{N}$ utilization and weight gain of Ethiopian Menz sheep. Small Rumin. Res. 1995, 18, 113-120. [CrossRef]

14. An, L.V.; Frankow-Lindberg, B.E.; Lindberg, J.E. Effect of harvesting interval and defoliation on yield and chemical composition of leaves; stems and tubers of sweet potato (Ipomoea batatas L. (Lam.)) plant parts. Field Crops Res. 2003, 82, 49-58. [CrossRef]

15. Ondabu, N.; Kitilit, J.K.; Mwangi, J. Evaluation of sweet potato vine cultivars as animal feed in Nakuru district, Kenya. In Proceedings of the African Crop Science Conference, Entebbe, Uganda, 17-21 December 2005; pp. 575-577.

16. Hadgu, G.Z.; Negesse, T.; Nurfeta, A. Chemical composition and in vitro dry matter digestibility of vines and roots of four sweet potato (Ipomoea batatas) varieties grown in southern Ethiopia. Trop. Subtrop. Agroecosyst. 2014, 17, 547-555.

17. CIP (Centro Internacional de la Papa). Sweetpotato in Africa; International Potato Centre: Lima, Peru, 2011; Available online: https://cipotato.org/research/sweetpotato-in-africa/ (accessed on 13 April 2018).

18. Etela, I.; Larbi, A.; Ikhatua, U.J.; Bamikole, M.A. Supplementing Guinea grass with fresh sweet potato foliage for milk production by Bunaji and N’Dama cows in early lactation. Livest. Sci. 2009, 120, 87-95. [CrossRef]

19. Phesatcha, K.; Wanapat, M. Performance of lactating dairy cows fed a diet based on treated rice straw and supplemented with pelleted sweet potato vines. Trop. Anim. Health Prod. 2013, 45, 533-538. [CrossRef]

20. Makkar, H.P.S. Feed supplementation block technology-Past, present and future. In Urea-Molasses Multinutrient Blocks: Simple and Effective Feed Supplement Technology for Ruminant Agriculture; Makkar, H.P.S., Sánchez, M., Speedy, A.W., Eds.; FAO: Rome, Italy, 2007; pp. 1-12.

21. Waruiru, R.M.; Onyando, C.O.; Machuka, R.O. Effect of feeding urea-molasses blocks with incorporated fenbendazole on grazing dairy heifers naturally infected with gastrointestinal nematodes. J. S. Afr. Vet. Assoc. 2003, 74, 49-52. [CrossRef] [PubMed]

22. Srinivas, B.; Gupta, B.N. Rumen fermentation, bacterial and total volatile fatty acid (TVFA) production rates in cattle fed on urea-molasses-mineral block licks supplement. Anim. Feed Sci. Technol. 1997, 65, 275-286. [CrossRef]

23. Hristov, A.N.; Ropp, J.K.; Grandeen, K.L.; Abedi, S.; Etter, R.P.; Melgar, A.; Foley, A.E. Effect of carbohydrate source on ammonia utilization in lactating dairy cows. J. Anim. Sci. 2005, 83, 408-421. [CrossRef] [PubMed]

24. Schwab, C.G.; Huhtanen, P.; Hunt, C.W.; Hvelplund, T. Nitrogen requirements of cattle. In Nitrogen and Phosphorous Nutrition of Cattle; Pfeffer, E., Hristov, A.N., Eds.; CAB International: Wallingford, UK, 2005; pp. 13-70.

25. Lukuyu, B.; Gachuiri, C.K.; Agili, S.; Leon-Velarde, C.; Kirui, J. Making High Quality Sweetpotato Silage: An Improved Tube Silage Making Method; International Potato Center: Nairobi, Kenya, 2012; Available online: https://cgspace.cgiar.org/handle/10568/89025 (accessed on 10 April 2018).

26. Ahnert, S.; Dickhoefer, U.; Schulz, F.; Susenbeth, A. Influence of ruminal Quebracho tannin extract infusion on apparent nutrient digestibility, nitrogen balance; and urinary purine derivatives excretion in heifers. Livest. Sci. 2015, 177, 63-70. [CrossRef]

27. Teeter, R.G.; Owens, F.N.; Mader, T.L. Ytterbium chloride as a marker for particulate matter in the rumen. J. Anim. Sci. 1984, 58, 465-473. [CrossRef]

28. Uden, P.; Colucci, P.E.; Van Soest, P.J. Investigation of chromium, cerium and cobalt as markers in digesta rate of passage studies. J. Sci. Food Agric. 1980, 31, 625-632. [CrossRef] 
29. Richter, H.; Schlecht, E. Accounting for marker disassociation when modelling time-dependent ruminal escape of particles based on the faecal excretion of Ytterbium. Anim. Feed Sci. Technol. 2006, 128, 135-154. [CrossRef]

30. AOAC (Association of Official Analytical Chemists). Official Methods of Analysis, 15th ed.; AOAC: Washington, DC, USA, 1990.

31. VDLUFA (Verband Deutscher Landwirtschaftlicher Untersuchungs- und Forschungsanstalten). Handbuch der landwirtschaftlichen Versuchs- und Untersuchungsmethodik Band III: Die Chemische Untersuchung von Futtermitteln; VDLUFA: Darmstadt, Germany, 2012.

32. Anderson, D.L.; Henderson, L.J. Sealed chamber digestion for plant nutrient analyses. Agron. J. 1986, 78, 937-939. [CrossRef]

33. Chen, X.B.; Gomez, M.J. Estimation of Microbial Protein Supply to Sheep and Cattle based on Urinary Excretion of Purine Derivatives-An Overview of the Technical Details; Rowett Research Institute: Bucksburn, UK, 1992.

34. Wassie, S.; Ali, A.I.M.; Korir, D.; Butterbach-Bahl, K.; Goopy, J.P.; Merbold, L.; Schlecht, E.; Dickhoefer, U. Effects of feed intake level on efficiency of microbial protein synthesis and nitrogen balance in Boran steers consuming tropical poor-quality forage. Arch. Anim. Nutr. 2019, 73, 140-157. [CrossRef] [PubMed]

35. Aregheore, E.M. Nutritive value of sweet potato (Ipomea batatas (L) Lam) forage as goat feed: Voluntary intake; growth and digestibility of mixed rations of sweet potato and Batiki grass (Ischaemum aristatum var. indicum). Small Rumin. Res. 2004, 51, 235-241. [CrossRef]

36. Korir, D.; Goopy, J.P.; Gachuiri, C.; Butterbach-Bahl, K. Supplementation with Calliandra calothyrsus improves nitrogen retention in cattle fed low-protein diets. Anim. Prod. Sci. 2016, 56, 619-626. [CrossRef]

37. Mlay, P.S.; Pereka, A.E.; Weisbjerg, M.R.; Hvelplund, T.; Madsen, J. Digestion and passage kinetics of fibre in mature dairy heifers maintained on poor quality hay as affected by the source and level of nitrogen supplementation. Anim. Feed Sci. Technol. 2003, 109, 19-33. [CrossRef]

38. Das, A.; Singh, G.P. Effect of different levels of berseem (Trifolium alexdrinum) supplementation of wheat straw on some physical factors regulating intake and digestion. Anim. Feed Sci. Technol. 1999, 81, 133-149. [CrossRef]

39. Giger-Reverdin, S. Characterisation of feedstuffs for ruminants using some physical parameters. Anim. Feed Sci. Technol. 2000, 86, 53-69. [CrossRef]

40. Ishida, H.; Suzuno, H.; Sugiyama, N.; Innami, S.; Tadokoro, T.; Maekawa, A. Nutritive evaluation on chemical components of leaves, stalks and stems of sweet potatoes (Ipomoea batatas Poir). Food Chem. 2000, 68, 359-367. [CrossRef]

41. Mu, T.H.; Tan, S.S.; Xue, Y.L. The amino acid composition; solubility and emulsifying properties of sweet potato protein. Food Chem. 2009, 112, 1002-1005. [CrossRef]

42. Abdulrazak, S.A.; Muinga, R.W.; Thorpe, W.; Ørskov, E.R. The effects of supplementation with Gliricidia sepium or Leucaena leucocephala forage on intake, digestion and live-weight gains of Bos taurus $\times$ Bos indicus steers offered Napier grass. Anim. Sci. 1996, 63, 381-388. [CrossRef]

43. Mathis, C.P.; Cochran, R.C.; Heldt, J.S.; Woods, B.C.; Abdelgadir, I.E.; Olson, K.C.; Titgemeyer, E.C.; Vanzant, E.S. Effects of supplemental degradable intake protein on utilization of medium- to low-quality forages. J. Anim. Sci. 2000, 78, 224-232. [CrossRef]

44. Aguerre, M.J.; Wattiaux, M.A.; Powell, J.M.; Broderick, G.A.; Arndt, C. Effect of forage-to-concentrate ratio in dairy cow diets on emission of methane, carbon dioxide, and ammonia, lactation performance, and manure excretion. J. Dairy Sci. 2011, 94, 3081-3093. [CrossRef] [PubMed]

45. Kennedy, P.M.; Charmley, E. Methane yields from Brahman cattle fed tropical grasses and legumes. Anim. Prod. Sci. 2012, 52, 225-239. [CrossRef]

46. McGinn, S.M.; Beauchemin, K.A.; Coates, T.; Colombatto, D. Methane emissions from beef cattle: Effects of monensin, sunflower oil, enzymes, yeast, and fumaric acid. J. Anim. Sci. 2004, 82, 3346-3356. [CrossRef] [PubMed]

47. Chaokaur, A.; Nishida, T.; Phaowphaisal, I.; Sommart, K. Effects of feeding level on methane emissions and energy utilization of Brahman cattle in the tropics. Agric. Ecosyst. Environ. 2015, 199, 225-230. [CrossRef]

48. Hammond, K.J.; Pacheco, D.; Burke, J.L.; Koolaard, J.P.; Muetzel, S.; Waghorn, G.C. The effects of fresh forages and feed intake level on digesta kinetics and enteric methane emissions from sheep. Anim. Feed Sci. Technol. 2014, 193, 32-43. [CrossRef] 
49. Janssen, P.H. Influence of hydrogen on rumen methane formation and fermentation balances through microbial growth kinetics and fermentation thermodynamics. Anim. Feed Sci. Technol. 2010, 160, 1-22. [CrossRef]

50. Buxton, D.R.; Redfearn, D.D. Plant limitations to fiber digestion and utilization. J. Nutr. 1997, 127, 814S-818S. [CrossRef] [PubMed]

51. Coleman, S.W.; Hart, S.P.; Sahlu, T. Relationships among forage chemistry, rumination and retention time with intake and digestibility of hay by goats. Small Rumin. Res. 2003, 50, 129-140. [CrossRef]

52. Goopy, J.P.; Donaldson, A.; Hegarty, R.; Vercoe, P.E.; Haynes, F.; Barnett, M.; Oddy, V.H. Low-methane yield sheep have smaller rumens and shorter rumen retention time. Br. J. Nutr. 2014, 111, 578-585. [CrossRef] [PubMed]

53. Petersen, S.O.; Sommer, S.G.; Béline, F.; Burton, C.; Dach, J.; Dourmad, J.Y.; Leip, A.; Misselbrook, T.; Nicholson, F.; Poulsen, H.D.; et al. Recycling of livestock manure in a whole-farm perspective. Livest. Sci. 2007, 112, 180-191. [CrossRef]

54. Hristov, A.N.; Oh, J.; Lee, C.; Meinen, R.; Montes, F.; Ott, T.; Firkins, J.; Rotz, A.; Dell, C.; Adesogan, A.; et al. Mitigation of Greenhouse Gas Emissions in Livestock Production-A Review of Technical Options for non-CO $\mathrm{CO}_{2}$ Emissions; FAO Animal Production and Health Paper 177; FAO: Rome, Italy, 2013.

(C) 2019 by the authors. Licensee MDPI, Basel, Switzerland. This article is an open access article distributed under the terms and conditions of the Creative Commons Attribution (CC BY) license (http://creativecommons.org/licenses/by/4.0/). 